\title{
Post-traumatic cluster headache: a clinical phenotype study of 16 patients
}

\author{
G Lambru*, CK Chan, MS Matharu \\ From The European Headache and Migraine Trust International Congress \\ London, UK. 20-23 September 2012
}

\section{Introduction}

Cluster headache $(\mathrm{CH})$ due to head trauma seems to be an extremely rare entity. To date only two cases of new onset $\mathrm{CH}$ that fulfill the criteria for post-traumatic headache have been described.

\section{Aims}

Describe the phenotype and response to treatments of a series of post-traumatic $\mathrm{CH}$ patients.

\section{Methods}

Sixteen cases fulfilling the International Headache Society (IHS) criteria for post-traumatic headache with the $\mathrm{CH}$ phenotype were identified out of a cohort of $302 \mathrm{CH}$ patients (chronic: 64\%) seen between 2007 and 2011. Details on the head injuries, along with clinical information on $\mathrm{CH}$ were collected.

\section{Results}

Five percent of our sample of patients had $\mathrm{CH}$ secondary to head trauma. All patients developed a chronic form of post-traumatic headache. Fourteen patients had chronic $\mathrm{CH}$ and 2 episodic $\mathrm{CH}(\mathrm{M}: \mathrm{F}=2: 1)$. The median age of onset of $\mathrm{CH}$ was 31 years (range: 10-54). Eight patients (50\%) reported a correspondence between the trauma site and the $\mathrm{CH}$ side. The most frequent circumstances of head traumas included: brawls in 5 patients (31\%) and sport accidents in 4 (25\%). No atypical clinical features were noticed. Remarkably, 3 patients (19\%) had familial $\mathrm{CH}$. Sumatriptan $6 \mathrm{mg}$ injection was effective in 15 patient; high dose and flow rate oxygen was effective in 5 patients. Verapamil was effective in 7 patients.

\section{Conclusion}

This is the largest series of post-traumatic $\mathrm{CH}$. This condition does not differ from the idiopathic form in terms of phenotype and response to treatment. The frequent occurrence of head injuries during brawls, may suggest a risktaking trait in some $\mathrm{CH}$ patients. The high proportion of familial $\mathrm{CH}$ in this series might suggest that exogenous factors, such as a head injury, may alter the homeostasis of the trigeminovascular system giving rise to $\mathrm{CH}$ particularly in genetically susceptible individuals.

Published: 21 February 2013

doi:10.1186/1129-2377-14-S1-P46

Cite this article as: Lambru et al:: Post-traumatic cluster headache: a clinical phenotype study of 16 patients. The Journal of Headache and Pain 2013 14(Suppl 1):P46.
Submit your manuscript to a SpringerOpen ${ }^{\circ}$ journal and benefit from:

- Convenient online submission

- Rigorous peer review

- Immediate publication on acceptance

- Open access: articles freely available online

- High visibility within the field

- Retaining the copyright to your article

Submit your next manuscript at $>$ springeropen.com 